\title{
Human Papillomavirus and Penile Cancers in Rio de Janeiro, Brazil: HPV Typing and Clinical Features
}

\author{
Marcos A. Scheiner, Mercia M. Campos, Antonio A. Ornellas, Eduardo W. Chin, Maria H. \\ Ornellas, Maria J. Andrada-Serpa
}

Hematology Service (MAS, MMC), Section of Urology (AAO, EWC) and Bone Marrow Transplant Center (MHO), National Cancer Institute (INCA) and Virology Service (MJAS), Evandro Chagas Institute of Clinical Research, Oswaldo Cruz Foundation, Rio de Janeiro, Brazil

\begin{abstract}
Objective: To determine the prevalence of human papillomavirus (HPV) DNA in penile cancers in Rio de Janeiro, Brazil.

Materials and Methods: We studied, prospectively, 80 consecutive cases of patients with penile cancers who underwent surgical treatment at three different Hospitals in Rio de Janeiro between March 1995 and June 2000. Of these patients, 72 were diagnosed with invasive squamous cell carcinoma and 8 patients with verrucous carcinoma. The following parameters were observed: presence or absence of HPV DNA viral type, histological subtypes, clinical stage and overall survival.

Results: HPV DNA was detected in $75 \%$ of patients with invasive carcinomas and in $50 \%$ of patients with verrucous carcinomas. High risk HPVs were detected in 15 of 54 (27.8\%) patients with HPV positive invasive tumors and in 1 of $4(25 \%)$ patients with HPV positive verrucous tumors. HPV 16 was the most frequent type observed. No correlation was observed between HPV status and histological subtype $(\mathrm{p}=0.51)$ as well as HPV status and stage stratification $(\mathrm{p}=0.88)$. HPV status was also not significantly associated with the presence of regional metastases $(p=0.89)$. The overall survival was related to the presence of lymph node metastases $(\mathrm{p}<0.0001)$.

Conclusions: HPV infection may have contributed to malignant transformation in a large proportion of our penile cancer cases but only inguinal metastasis was a prognostic factor for survival in these patients with penile carcinoma.
\end{abstract}

Key words: human papillomavirus; penile cancer; Brazil

Int Braz J Urol. 2008; 34: 467-76

\section{INTRODUCTION}

Penile cancer prevalence varies according to geographic region and ethnic origin (1). In Brazil, penile cancer represents $2 \%$ of all cancers in males and is more frequent in north and northeast regions with an incidence ranging from 1.3 to 2.7 per 100,000 , according to the geographic region (2).

The mechanism by which Human Papillomavirus (HPV) leads to malignant transformation is likely mediated through two viral genes, E6 and E7, which are actively transcribed in HPV infected cells. The E6 and E7 proteins bind to and inactivate the host cell's tumor suppressor gene products $\mathrm{p} 53$ and $\mathrm{pRb}$, leading to uncontrolled growth. Although HPV genes have been detected in nearly $100 \%$ of cervical cancers, the presence of HPV infection in penile cancer is highly variable (3). HPV has been recognized as a possible etiological agent for penile carcinoma but its role in disease development and correlation to prognosis is still unclear. 
HPV infections are associated with benign and malignant epithelial lesions and a high-risk HPV group is probably the major cause of anogenital cancers. To date, more than 100 HPV genotypes have been identified. Recently, Munoz et al. (4) pooled data from 11 case-control studies from nine countries and classified the following $15 \mathrm{HPV}$ genotypes into a high-risk group: 16,18,31,33,35,39,45,51,52,56,58 $, 59,68,73$ and 82 . Three other genotypes [26, 53 and 66] will almost certainly also be classified as part of the high-risk group (4).

The prevalence of HPV infections in penile cancer is similar to those observed in vulvar carcinoma (3). Additionally, specific histological subtypes of penile cancer are consistently associated with HPV infection - basaloid and warty squamous cell carcinoma $(3,5)$.

In Brazil, few studies have reported HPV infection in penile cancer. McCance et al. (6) showed a positivity of $49 \%$ using Southern blot for the detection of HPV DNA, while Bezerra et al. (7) reported a prevalence of $30.5 \%$ for HPV DNA in paraffin-embedded material using the polymerase chain reaction (PCR).

The aim of the present study was to assess the prevalence of HPV infection in a large series of patients with invasive squamous cell carcinoma and verrucous carcinoma of the penis.

Verrucous carcinoma is a less aggressive variant of squamous cell penile carcinoma, which rarely metastasizes to regional nodes regardless of size, evidence of local invasion or duration of disease (8).

Invasive squamous cell carcinoma of the penis usually metastasizes to the inguinal region though lymphatic channels and approximately $20 \%$ of the patients whose nodes appear to be clinically normal have inguinal metastasis at operation.

\section{MATERIALS AND METHODS}

\section{Histopathological Specimens}

Eighty penile cancer specimens were collected from patients from three different Hospitals in Rio de Janeiro: Brazilian National Cancer Institute,
Pedro Ernesto University Hospital and Mario Kröeff Cancer Hospital between March 1995 and June 2000. All patients were evaluated prospectively and gave their informed consent to participate in the study. Our Institutional Review Board also approved the study.

\section{Specimen Processing and DNA Extraction}

Two to five $\mathrm{cm}$ fragments were collected from the tumor region during surgical procedure and frozen at $-80^{\circ} \mathrm{C}$ or immediately processed. The specimens were washed in saline and cut into small pieces. Samples were then digested with $50 \mu \mathrm{L}$ of proteinase $\mathrm{K}(10 \mathrm{mg} / \mathrm{mL})$ in a volume of $3 \mathrm{~mL}$ of cell lyses solution (10 mM Tris-HCl pH 7.6, 10 mM EDTA $\mathrm{pH} 8.0$ and $50 \mu$ Lof SDS $10 \%)$ and incubated at $42^{\circ} \mathrm{C}$ for 14 to 16 hours. DNA was recovered after ethanol precipitation, dried at room temperature and dissolved in sterile water. HeLa cell line DNA was used as an HPV positive control (9). All samples were tested for DNA integrity by amplification of a fragment of the $\beta$-globin gene using PC04/GH20 as primers.

\section{PCR Reaction}

All samples were first subjected to an amplification using a generic pair of primers (MY09/MY11) for HPV (10) that amplify a fragment of the conserved $\mathrm{L} 1$ region. The DNA sample was amplified in $50 \mu \mathrm{L}$ reactions. DNA from a HeLa cell line infected with HPV-18, was used as a positive control. All positive samples using the generic primers were amplified with a specific pair of primers for HPV-16 and HPV18. The expected PCR products were fragments of $450-452 \mathrm{bp}$ for generic primers, $268 \mathrm{bp}$ for $\beta$ globin primers, 120 and 100 bp with HPV 16 and 18 specific primers, respectively. Amplicons were analyzed by electrophoresis in a $1.5 \%$ agarose gel stained with $10 \mu \mathrm{g} / \mathrm{mL}$ of ethidium bromide. Samples identified as positive for HPV DNA were genotyped by restriction fragment length polymorphism (RFLP). Specimens were examined without prior knowledge of the histology of the lesions.

DNA samples that were negative for the first round MY9/11 primer sets were re-amplified in a nested PCR using the GP5+/6+ primer pair (11). The 
number of cycles was reduced to 30 and $2.5 \mu \mathrm{L}$ of template was used (12). Strict laboratory conditions were followed in order to avoid contamination.

\section{Restriction Fragment Length Polymorphism Analysis}

The amplicons obtained by the MY9/11 primer sets were submitted to RFLP using the enzymes BamHI, DdeI, HaeIII, RsaI and Sau3AI. The digested and non-digested PCR products were analyzed in $12 \%$ polyacrylamide gels. The gels were stained with ethidium bromide and photographed. Fragments were analyzed according to Bernard et al. (13).

\section{Clinicopathological Data}

Specimens from 72 patients histologically diagnosed with invasive squamous cell carcinoma and specimens from 8 patients diagnosed with verrucous carcinoma were analyzed. Patients with verrucous penile carcinoma were studied to assess the prevalence of HPV infection. Patients with invasive squamous cell carcinoma of the penis were studied to assess the prevalence of HPV infection. Stage was based on clinical ground, final stage was determined at the time of presentation according to the 1978 TNM system and were further clinically classified according to the AJCC Cancer Staging Manual [AJCC, 2002] (14). Patients were clinically observed during a median of 15 months. We defined stage stratification into group I (T1N0), II (T1N1,T2N0-1), III (T1N2,T2N2,T3N0-2) and IV (T1-3N3,T4N0-3).

The pathological material collected from patients with invasive squamous cell carcinoma was reviewed and all tumors were classified according to the Broder's grading system.

\section{Statistical Analysis}

Patient follow-up was gathered from medical charts from the Brazilian National Cancer Institute and when necessary through contact with the patient's family. The data obtained were recorded on standard research forms and filed in a database. Analyses were performed using SPSS ${ }^{\circledR}$. Association with clinical stage, histopathological subtype and HPV status was done using the chi-square test. A "p" value $<0.05$ was considered statistically significant. Analysis of actuarial survival rates was performed by the KaplanMeier method and log rank test. Differences were considered significant when the " $p$ " value was less than 0.05 .

\section{RESULTS}

A total of 80 specimens of penile tumors from an equal number of patients were analyzed. Patients were clinically observed during a median of 15 months (1 to 80 months). The mean age of patients was 57.6 years (ranging from 36 to 86 years) and no statistical difference was observed between HPV positive and negative patients.

The glans was the most frequent site involved and tumors were classified as follows: 8 $(10 \%)$ cases of verrucous carcinoma and 72 (90\%) invasive squamous cell carcinoma of penis. Of the 72 patients with invasive carcinoma, $16(22.2 \%)$ patients presented well differentiated, $53(73.6 \%)$ moderately differentiated and $3(4.2 \%)$ poorly differentiated tumors.

The distribution category $\mathrm{T}$ in all 72 cases with invasive squamous cell carcinoma of the penis included $8(11.1 \%)$ in clinical stage T1, $23(31.9 \%)$ in clinical stage T2, $24(33.3 \%)$ in clinical stage T3 and $15(20.8 \%)$ in clinical stage $\mathrm{T} 4$. The remaining 2 patients $(2.8 \%)$ in clinical stage TX were included because they had been referred to our institution after surgical treatment of the primary tumor. The $\mathrm{N}$ category distribution in the 72 cases included 32 (44.4\%) in stage N0, $7(9.7 \%)$ in stage N1, $19(26.4 \%)$ in stage $\mathrm{N} 2$ and $13(18 \%)$ in stage N3. The one remaining patient was classified as T2NXM0. The lymph nodes could not be evaluated in one patient (1.4\%) classified as stage NX.

Of the 72 cases, 7 (9.7\%) were included in group I according to stage stratification, $17(23.6 \%)$ in group II, 22 (30.5\%) in group III and $24(33.3 \%)$ in group IV. Two patients did not provide requirements for the inclusion in stage stratification groups. No correlation was observed between HPV status and stage stratification $(\mathrm{p}=0.88)$. 
Of the 72 patients, $25(34.7 \%)$ presented lymph node metastases. The 5-year disease-free survival rates for patients with negative and positive lymph node involvement were $80 \%$ and $0 \%$ respectively. Differences between the 2 groups were statistically significant ( $p<0.001$, Figure-1). HPV status was also not significantly associated with the presence of regional metastases $(\mathrm{p}=0.89)$.

None of the 8 patients with verrucous carcinoma developed local recurrences or distant metastases and $31 / 72$ patients $(43 \%)$ with invasive carcinomas died due to progression of the malignancy.

HPV DNA was detected in 44\% (35 of 80) of patients using the MY9/11 first round PCR. The overall detection of HPV DNA increased to $72.5 \%$ (58 of 80) using the nested GP5+/6+ PCR. A fragment of the $\beta$-globin gene was amplified in all specimens as a control of DNA integrity. After RFLP typing of twenty-three HPV+ cases, high risk HPVs were detected in $69 \%$ (16 of 23) while low risk HPVs were found in 7 positive cases. The HPV 16 type was observed in 12 of 23 (52\%) cases.

Table-1 shows HPV genotyping according to the histopathological subtype. The distribution of positive and negative HPV tumors, according to the histopathological grade of differentiation and clinical stage, is shown in Table-2. No statistical correlation was observed between HPV status and histopathological subtype $(\mathrm{p}=0.51)$.

HPV positive patients had better 5-year disease-free survival rates than those with negative HPV results although the differences between the 2 groups were not significant $(\mathrm{p}=0.779$, Figure2).

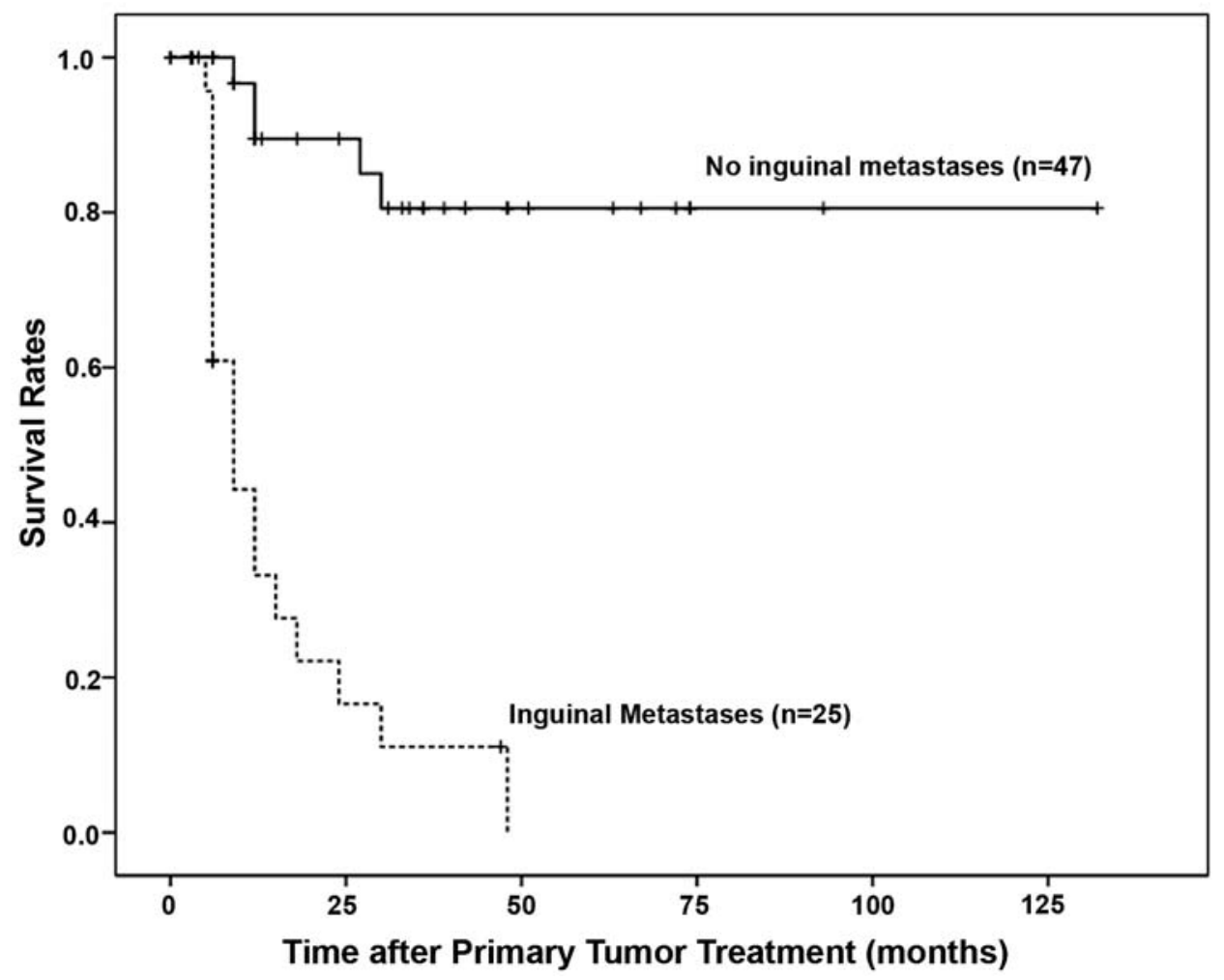

Figure 1 - Respective 10-year survival rates according to the presence $(n=25)$ or absence of inguinal metastases $(n=47)$. KaplanMeier method $(p<0.0001, \log$ rank test). 
Human Papillomavirus and Penile Cancer

Table 1 - HPV genotyping of penile tumors according to the pathological subtype.

\begin{tabular}{|c|c|c|c|c|c|c|c|c|c|c|c|}
\hline \multirow{2}{*}{$\begin{array}{l}\text { Histopathological } \\
\text { Subtype }\end{array}$} & \multirow[b]{2}{*}{$\mathbf{N}$} & \multirow[b]{2}{*}{$\mathrm{HPV}+(\%)$} & \multicolumn{9}{|c|}{ Genotypes } \\
\hline & & & 6 & $16 *$ & $18^{*}$ & 28 & $31 \%$ & $33 *$ & $45 *$ & 71 & NT \\
\hline Ver & 8 & $4 / 80$ & 1 & $1 *$ & & & & & & & 2 \\
\hline WD & 16 & $11 / 80$ & 2 & $1^{*}$ & & & & $1 *$ & & 1 & 6 \\
\hline MD & 53 & $40 / 80(50)$ & 1 & $8 *$ & $1 *$ & 1 & $1^{*}$ & & $1 *$ & & 27 \\
\hline PD & 3 & $3 / 80(3.8)$ & & $2 *$ & & 1 & & & & & 0 \\
\hline Total & 80 & $58 / 80(72.5)$ & 4 & $12 *$ & $1 *$ & 2 & $1 *$ & $1 *$ & $1 *$ & 1 & 35 \\
\hline
\end{tabular}

$\overline{V e r}=$ verrucous carcinoma WD = well differentiated squamous cell carcinoma; $M D=$ moderately differentiated squamous cell carcinoma; $P D=$ poorly differentiated squamous cell carcinoma; NT not typed. HPV = human papillomavirus; Asterisks indicate high-risk HPV types.

\section{COMMENTS}

Age-standardized HPV prevalence varied nearly 20 times between normal populations, from $1.4 \%(95 \%$ CI $0.5-2.2)$ in Spain to $25.6 \%$ (22.428.8 ) in Nigeria (15). The present study evaluated the prevalence of HPV DNA in the largest series of penile tumors, in Rio de Janeiro, Brazil. Squamous cell carcinoma represents $90 \%$ of penile cancers. In our series, $70.3 \%$ of cases were moderately differentiated SCC. Seventy-two percent (58 of 80) of specimens were HPV DNA positive. This frequency was different from previous reported in Brazil. Bezerra et al. detected HPV DNA in 30.5\% (25 out of 82) of penile carcinomas in the State of Sao Paulo (7). Heideman et al. (16) detected HPV 46 of 83 (55\%) penile squamous cell carcinomas (SCCs). HPV16 was the predominant type, appearing in $24(52 \%)$ of 46 of penile SCCs. The reported HPV prevalence of penile carcinoma is highly variable, ranging from 15 to $71 \%$ (3). Probably the variability in HPV detection in these different studies represents a true difference and or technical discrepancies. High risks HPVs were detected in $27.5 \%$ (16 of 58 ) of our penile carcinomas.

Table 2 - HPV DNA positive and negative penile cancer according to the histopathological subtypes and clinical stage.

\begin{tabular}{|c|c|c|c|c|c|c|c|c|}
\hline \multirow[t]{2}{*}{$\begin{array}{c}\text { Histopathological } \\
\text { Subtypes }\end{array}$} & \multicolumn{4}{|c|}{$\begin{array}{l}\text { N of HPV Positive } \\
\text { Clinical Stage }\end{array}$} & \multicolumn{4}{|c|}{$\begin{array}{l}\text { N of HPV Negative } \\
\text { Clinical Stage }\end{array}$} \\
\hline & I & II & III & IV & I & II & III & IV \\
\hline Ver & 0 & 2 & 2 & 0 & 2 & 1 & 1 & 0 \\
\hline WD & 2 & 1 & 3 & 5 & 0 & 0 & 5 & 0 \\
\hline MD & 4 & 10 & 12 & 14 & 1 & 5 & 1 & 4 \\
\hline PD & 0 & 1 & 1 & 1 & 0 & 0 & 0 & 0 \\
\hline Total & 6 & 14 & 18 & 20 & 3 & 6 & 7 & 4 \\
\hline
\end{tabular}

Ver = verrucous carcinoma; $W D=$ well differentiated squamous cell carcinoma; $M D=$ moderately differentiated squamous cell carcinoma; $P D=$ poorly differentiated squamous cell carcinoma. HPV = human papillomavirus; No correlation was observed between HPV status and histological subtypes $(p=0.51)$ as well as HPV status and stage stratification $(p=0.88)$. 
The most frequent viral type detected in penile carcinoma was HPV 16 , observed in $20.7 \%$ (12 of 58) of cases. This result was similar to that previous reported for anogenital cancers. Low risk HPVs were observed in 7 of $58(12 \%)$ positive carcinomas and HPV 6 was the most frequent type, which was found in 4 cases. In Argentina, Picconi et al. (17) reported a very high prevalence of HPV in penile carcinomas $(71 \%)$ and HPV 18 was the most frequent type found.

Although, our HPV positive patients had better 5-year disease-free survival rates than those with negative HPV results the differences between the 2 groups were not significant $(\mathrm{p}=0.779$, Figure-2).

Lont et al. (18) also detected high-risk HPV DNA in $29 \%$ of the tumors, with HPV 16 being the predominant type, accounting for $76 \%$ of high-risk HPV containing SCCs. Disease-specific 5-year survival in the high-risk HPV-negative group and high-risk HPV-positive group was $78 \%$ and $93 \%$, respectively (log-rank test $\mathrm{p}=0.03)$. In multivariate analysis, the HPV status was an independent predictor for disease-specific mortality $(\mathrm{p}=0.01)$. These results indicate that the presence of high-risk HPV (29\%) confers a survival advantage in patients with penile carcinoma.

In our study, only one case of HPV 18 was observed. Thirty-five of 58 patients $(60.3 \%)$ with non-16 and non-18 positive cases could not be typed. No multiple HPV infections were detected. Multiple infections were observed in $11.6 \%$ of Chinese women (19) with cervical cancer and in $8.5 \%$ of penile tumors (3). Although, multiple HPV types are less frequent, our results may be due to differences in the ability of the set of primers to amplify different amounts and combinations of HPV types within a sample as well as the capacity of RFLP analysis to identify multiple infections (20).

No correlation was observed among histopathological subtypes of invasive squamous cell penile carcinomas and HPV infection $\left(\mathrm{x}^{2}=0.43\right.$ and

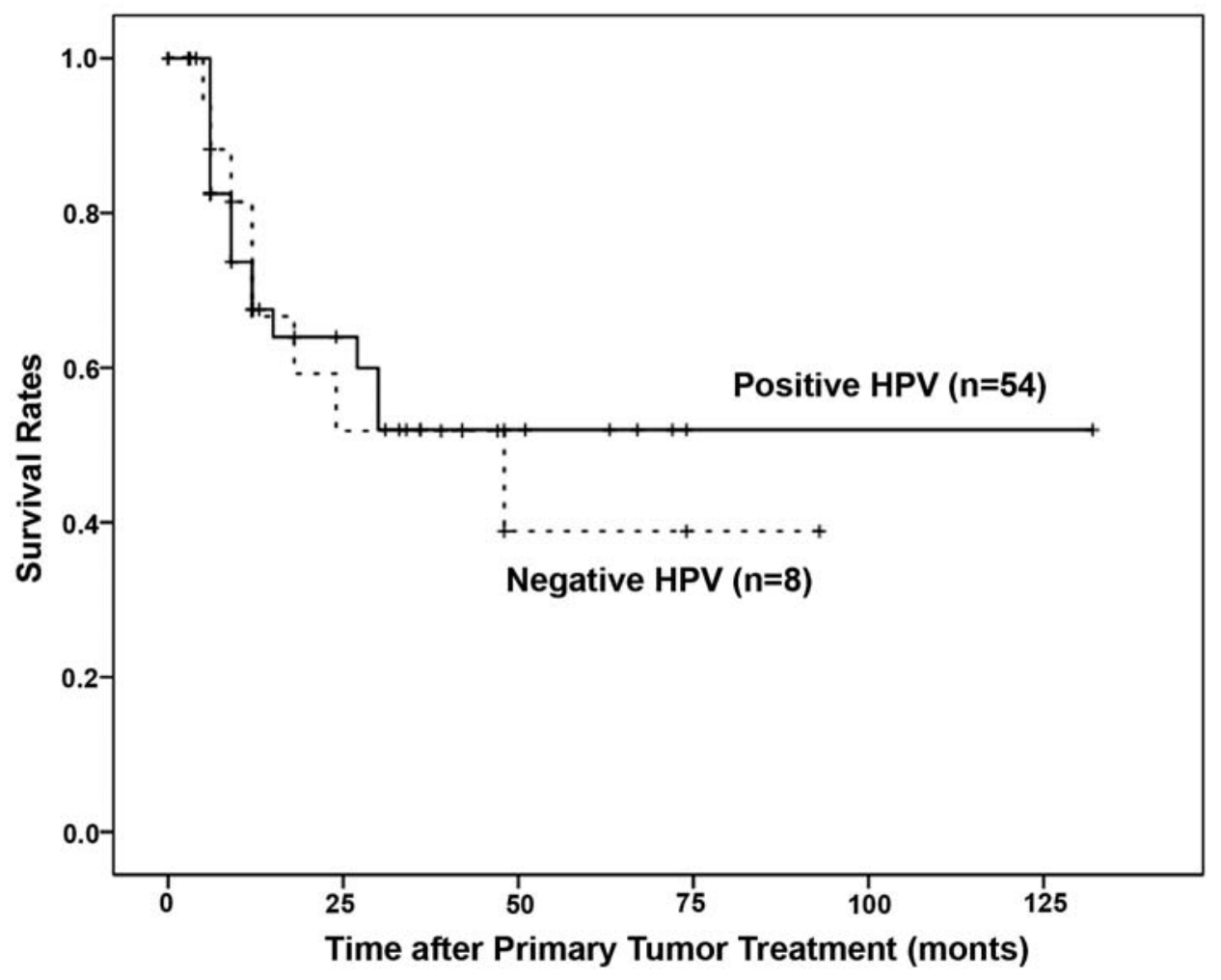

Figure 2 - Respective 10-year survival rates according to the presence $(n=54)$ or absence of Human Papillomavirus $(n=18)$. KaplanMeier method ( $p=0.779$, not significant, log rank test). 
$\mathrm{p}=0.51$ ), although the majority of HPV DNA positive cases (54) were observed among the moderately and poorly differentiated carcinomas.

Seven of 8 cases of verrucous carcinomas were HPV DNA positive and one presented high risk HPV 16. In a previous report, Rubin et al. (3) related 4 of 12 verrucous carcinomas as being HPV DNA positive including 2 with high-risk HPVs. On the other hand, previous studies showed that verrucous carcinoma is more often HPV negative or low-risk HPV positive $(21,22)$.

The majority of penile cancer cases (40\%) occurred in the fifth and sixth decade of life. Lymph node metastasis was associated with poor survival rate and no difference was observed in survival between HPV positive and HPV DNA negative cases.

Although the central role of HPV infection in the etiology of cervical cancer has been recognized, HPV infection alone is insufficient for the malignant transformation in penile cancer. In addition, the presence of HPV DNA could not be considered a prognostic factor. Several epidemiological reports indicate that other factors such as the lack of circumcision, hygiene practices, the presence of other sexually transmitted diseases, the number of sexual partners and cigarette smoking may predispose to penile carcinogenesis, and the exact role of HPV infection in the development of penile cancers remains to be elucidated.

On June 8, 2006, the U.S. Food and Drug Administration approved the use of a new vaccine to prevent infection from four types of HPV. Two of the HPV types targeted by the vaccine (HPV-16 and HPV18) are responsible for about 70 percent of the cases of cervical cancer worldwide. The other two HPV types (HPV-6 and HPV-11) cause approximately 90 percent of the cases of genital warts. The vaccine is currently recommended for use in young females before they become sexually active, and its possible use in males is under scrutiny. One of several reasons that HPV vaccines have focused on women rather than men is that cervical cancer accounts for 80 percent of HPV-related cancers. Male cancers are obviously in the minority, but 20 percent is still significant, especially considering the prevalence of HPV infection. While women have about 80 percent of the total burden of disease and death, it is certainly not inconsequential for men. Penile cancer affects 100,000 men a year worldwide, and the numbers are increasing. As a global issue, penile cancer is a relevant problem. For heterosexual men, the main benefits of an HPV vaccine will be the prevention of genital warts and, potentially, cervical cancer in women. While studies have not yet been carried out, the hope is that the vaccine may eventually help prevent cancers linked to HPV, including penile cancers. If the vaccine proves successful, the administration of HPV vaccines could eventually become a requirement for boys and girls in middle school or high school as a potential way to reduce HPV infection (23).

Improved sampling techniques of the male genitalia and cohort studies in progress should provide important information on the natural history of HPV infection and disease in men, including risk factors for HPV acquisition and transmission. The impact on HPV infection in males of the vaccination in women will also need to be assessed.

\section{ACKNOWLEDGEMENTS}

This work was supported by the Brazilian Council for Scientific and Technological Development (CNPQ) and Ary Frauzino Foundation, National Institute of Cancer.

\section{CONFLICT OF INTEREST}

None declared

\section{REFERENCES}

1. Dillner J, von Krogh G, Horenblas S, Meijer CJ: Etiology of squamous cell carcinoma of the penis. Scand J Urol Nephrol Suppl. 2000; 205: 189-93.

2. Parkin DM, Whelan SL, Ferlay J, Raymond L, Young J: Cancer Incidence in Five Continents VII. Lyon, IARC Scientific Publications; \#143 (www.iarc.fr). 1997.

3. Rubin MA, Kleter B, Zhou M, Ayala G, Cubilla AL, Quint WG, et al.: Detection and typing of human papillomavirus DNA in penile carcinoma: evidence for multiple independent pathways of penile carcinogenesis. Am J Pathol. 2001; 159: 1211-8.

4. Muñoz N, Bosch FX, de Sanjosé S, Herrero R, Castellsagué X, Shah KV, et al.: Epidemiologic classification of human papillomavirus types associated with cervical cancer. N Engl J Med. 2003; 348: 518-27. 
5. Bezerra AL, Lopes A, Landman G, Alencar GN, Torloni H, Villa LL: Clinicopathologic features and human papillomavirus dna prevalence of warty and squamous cell carcinoma of the penis. Am J Surg Pathol. 2001; 25: 673-8.

6. McCance DJ, Kalache A, Ashdown K, Andrade L, Menezes F, Smith P, et al.: Human papillomavirus types 16 and 18 in carcinomas of the penis from Brazil. Int J Cancer. 1986; 37: 55-9.

7. Bezerra AL, Lopes A, Santiago GH, Ribeiro KC, Latorre MR, Villa LL: Human papillomavirus as a prognostic factor in carcinoma of the penis: analysis of 82 patients treated with amputation and bilateral lymphadenectomy. Cancer. 2001; 91: 2315-21.

8. Seixas AL, Ornellas AA, Marota A, Wisnescky A, Campos F, de Moraes JR: Verrucous carcinoma of the penis: retrospective analysis of 32 cases. J Urol. 1994; 152: 1476-8; discussion 1478-9.

9. Boshart M, Gissmann L, Ikenberg H, Kleinheinz A, Scheurlen W, zur Hausen H: A new type of papillomavirus DNA, its presence in genital cancer biopsies and in cell lines derived from cervical cancer. EMBO J. 1984; 3: 1151-7.

10. Manos MM, Ting Y, Wright DK, Lewis AJ, Broker TR, Wolinsky SM: The use of polymerase chain reaction amplification for the detection of genital human papillomaviruses. Molecular Diagnostics of Human Cancer. Cancer Cells. 1989; 7: 209-14.

11. Jacobs MV, de Roda Husman AM, van den Brule AJ, Snijders PJ, Meijer CJ, Walboomers JM: Group-specific differentiation between high- and low-risk human papillomavirus genotypes by general primer-mediated PCR and two cocktails of oligonucleotide probes. J Clin Microbiol. 1995; 33: 901-5.

12. Remmerbach TW, Brinckmann UG, Hemprich A, Chekol M, Kühndel K, Liebert UG: PCR detection of human papillomavirus of the mucosa: comparison between MY09/11 and GP5+/6+ primer sets. J Clin Virol. 2004; 30: 302-8.

13. Bernard HU, Chan SY, Manos MM, Ong CK, Villa LL, Delius H, et al.: Identification and assessment of known and novel human papillomaviruses by polymerase chain reaction amplification, restriction fragment length polymorphisms, nucleotide sequence, and phylogenetic algorithms. J Infect Dis. 1994; 170: 1077-85. Erratum in: J Infect Dis 1996; 173: 516.

14. American Joint Committee on Cancer: AJCC Cancer Staging Manual 6th. Penis. New York, Springer. 2002; pp. 303-308.

15. Clifford GM, Gallus S, Herrero R, Muñoz N, Snijders PJ, Vaccarella S, et al.: Worldwide distribution of human papillomavirus types in cytologically normal women in the International Agency for Research on Cancer HPV prevalence surveys: a pooled analysis. Lancet. 2005; 366: 991-8.

16. Heideman DA, Waterboer T, Pawlita M, Delis-van Diemen P, Nindl I, Leijte JA, et al.: Human papillomavirus-16 is the predominant type etiologically involved in penile squamous cell carcinoma. J Clin Oncol. 2007; 25: 4550-6.

17. Picconi MA, Eiján AM, Distéfano AL, Pueyo S, Alonio LV, Gorostidi S, et al.: Human papillomavirus (HPV) DNA in penile carcinomas in Argentina: analysis of primary tumors and lymph nodes. J Med Virol. 2000; 61: 65-9.

18. Lont AP, Kroon BK, Horenblas S, Gallee MP, Berkhof J, Meijer CJ, et al.: Presence of high-risk human papillomavirus DNA in penile carcinoma predicts favorable outcome in survival. Int J Cancer. 2006; 119: 107881.

19. Chan PK, Li WH, Chan MY, Ma WL, Cheung JL, Cheng AF: High prevalence of human papillomavirus type 58 in Chinese women with cervical cancer and precancerous lesions. J Med Virol. 1999; 59: 232-8.

20. Qu W, Jiang G, Cruz Y, Chang CJ, Ho GY, Klein RS, et al.: PCR detection of human papillomavirus: comparison between MY09/MY11 and GP5+/GP6+ primer systems. J Clin Microbiol. 1997; 35: 1304-10.

21. Gregoire L, Cubilla AL, Reuter VE, Haas GP, Lancaster WD: Preferential association of human papillomavirus with high-grade histologic variants of penile-invasive squamous cell carcinoma. J Natl Cancer Inst. 1995; 87: 1705-9.

22. Noel JC, Vandenbossche M, Peny MO, Sassine A, de Dobbeleer G, Schulman CC, et al.: Verrucous carcinoma of the penis: importance of human papillomavirus typing for diagnosis and therapeutic decision. Eur Urol. 1992; 22: 83-5.

23. Geipert N: Vaccinating men for HPV: new strategy for preventing cervical cancer in women? J Natl Cancer Inst. 2005; 97: 630-1.

Accepted after revision:

May 30, 2008

Correspondence address:

Dr. Antonio Augusto Ornellas

Section of Urology

Instituto Nacional de Câncer

Praça da Cruz Vermelha 23

Rio de Janeiro, RJ, Brazil

E-mail: ornellasa@hotmail.com 


\section{EDITORIAL COMMENT}

This study is very welcome as it demonstrates the high rate of human papillomavirus (HPV) associated with penile cancer. The detection rate of $75 \%$ approaches the rate of $90 \%$ seen in carcinoma in-situ. Other studies show lower HPV rates. It was unclear if this was due to differences in technique, such as immunohistochemistry or due to real variations in biology. Furthermore, the lower rate of HPV (50\%) in verrucous type indicates a possible different etiology to this subset of cancer. Studying the subtypes of HPV associated with penile cancer is paramount currently, given the recent development of vaccines against specific subtypes of HPV. It is hard to project the effect mass vaccination of females will have on males, but ought to reduce carriage of HPV among heterosexual males. Vaccinating males may have benefits for females also, as total immunization of the whole female population is unlikely. Reduc- ing the overall population pool of these subtypes is likely to benefit both males and females. The impact on the incidence and type of penile cancer is likely have a lead time of several decades, as only a quarter of men with penile cancer present under the age of 50. Projections must also take into account the increasing life-expectancies in developed countries with more men living into their $70 \mathrm{~s}$ and $80 \mathrm{~s}$, where the disease is more prevalent (see http:// www.oecd. org/statsportal/). Thus in the absence of any vaccination the prevalence is likely to increase, whereas even with successful vaccination changes in demographics may reduce the benefit in the initial years. Finally, the subtypes of HPV being targeted may result in only some cancers being prevented. These factors must be brought together in modeling and scenario planning when formulating strategies for service provision in any healthcare system.

\author{
Dr. P. K. Hegarty \\ Institute of Urology and Pathology \\ University College Hospital London \\ London, UK \\ E-mail:Paulhego@hotmail.com
}

\section{EDITORIAL COMMENT}

The prevalence of penile cancer in Brazil is $2 \%$ and this is higher than in the USA and Europe, where it accounts for 0.3 to $0.6 \%$ of cancers $(1,2)$. Squamous cell carcinoma (SCC) is the most common histological type of penile cancer and represents $95 \%$ of cases. However the aetiology of penile cancer is unknown, risk factors include age and lack of circumcision $(1,2)$. Other predisposing factors to the development of penile SCC are the chronic inflammatory disorder penile lichen sclerosus (LS) (also termed balanitis xerotica obliterans) (3-6) or human papillomavirus (HPV) infection $(1,2,7,8)$. A common aetiology for penile and cervical cancer is suggested by the geographical correlation between the incidence of penile and cervical cancers worldwide (9). The persistent infection with sexually transmitted high risk HPV is the main cause of cervical cancer $(10,11)$. The prevalence of HPV penile infections in healthy men is reported to be 39\% in Brazil and 3-9\% in Western Europe, where there is a lower incidence of penile cancer $(12,13)$. However, HPV detection in penile cancer cases varies from $20-80 \%$, depending on detection method and geographical location $(1,2)$. This is unlike cervical cancer where HPV infection can be detected in almost all cases (10).

The paper entitled "Human Papillomavirus and Penile Cancers in Rio de Janeiro, Brazil: HPV Typing and Clinical Features" concerns penile cancer HPV infection and survival in 80 consecutive 
cases of patients who underwent surgery at Hospitals in Rio de Janeiro between 1995 and 2000. High risk HPV 16 was the predominate HPV type detected and no correlation was observed between HPV status (all types) and penile cancer subtype, stage, regional metastases or survival. HPV 16 has previously been reported to predominate in penile lichen sclerosus and SCC and may be an aetiological agent in the development of a significant proportion of penile cancers $(7,14)$. However the importance of HPV status in penile cancer progression and patient survival is controversial, as high-risk HPV is associated with aggressive variants (8) but recent series examining the relationship of HPV infection with prognosis have revealed either no correlation survival or a favourable survival $(15,16)$. This study from Rio de Janeiro is consistent with only inguinal metastasis being a prognostic factor for penile cancer survival. In summary, high risk HPV infection occurs in penile SCC and it is likely to be an aetiological agent in the development of a significant proportion of penile cancers. These results are important as prophylactic HPV vaccines for prevention of cervical cancer in women could also prevent penile cancers in men. However, several studies, including this one, show that once penile cancer has developed poor prognosis is associated with the occurrence of lymph node metastasis and not HPV status.

\section{REFERENCES}

1. Micali G, Nasca MR, Innocenzi D, Schwartz RA: Penile cancer. J Am Acad Dermatol. 2006; 54: 369-91.

2. Kayes O, Ahmed HU, Arya M, Minhas S: Molecular and genetic pathways in penile cancer. Lancet Oncol. 2007; 8: 420-9.

3. Nasca MR, Innocenzi D, Micali G: Penile cancer among patients with genital lichen sclerosus. J Am Acad Dermatol. 1999; 41: 911-4.

4. Depasquale I, Park AJ, Bracka A: The treatment of balanitis xerotica obliterans. BJU Int. 2000; 86: 459-65.

5. Powell J, Robson A, Cranston D, Wojnarowska F, Turner R: High incidence of lichen sclerosus in patients with squamous cell carcinoma of the penis. $\mathrm{Br}$ J Dermatol. 2001; 145: 85-9.

6. Pietrzak P, Hadway P, Corbishley CM, Watkin NA: Is the association between balanitis xerotica obliterans and penile carcinoma underestimated? BJU Int. 2006; 98: 74-6.

7. Prowse DM, Ktori EN, Chandrasekaran D, Prapa A, Baithun S: Human papillomavirus-associated increase in p16INK4A expression in penile lichen sclerosus and squamous cell carcinoma. Br J Dermatol. 2008; 158: 261-5.

8. Gregoire L, Cubilla AL, Reuter VE, Haas GP, Lancaster WD: Preferential association of human papillomavirus with high-grade histologic variants of penile-invasive squamous cell carcinoma. J Natl Cancer Inst. 1995; 87: 1705-9.

9. Parkin DM, Bray F: Chapter 2: The burden of HPVrelated cancers.Vaccine. 2006; (Suppl 3): S11-25.

10. zur Hausen H: Papillomaviruses and cancer: from basic studies to clinical application. Nat Rev Cancer. 2002; 2: 342-50.

11. de Villiers EM, Fauquet C, Broker TR, Bernard HU, zur Hausen $\mathrm{H}$ : Classification of papillomaviruses. Virology. 2004;324: 17-27.

12. Franceschi S, Castellsagué X, Dal Maso L, Smith JS, Plummer M, Ngelangel C, et al.: Prevalence and determinants of human papillomavirus genital infection in men. Br J Cancer. 2002; 86: 705-11.

13. Nasca MR, Innocenzi D, Micali G: Association of penile lichen sclerosus and oncogenic human papillomavirus infection. Int J Dermatol. 2006; 45: 681-3.

14. Rubin MA, Kleter B, Zhou M, Ayala G, Cubilla AL, Quint WG, et al.: Detection and typing of human papillomavirus DNA in penile carcinoma: evidence for multiple independent pathways of penile carcinogenesis. Am J Pathol. 2001; 159: 1211-8.

15. Lont AP, Kroon BK, Horenblas S, Gallee MP, Berkhof J, Meijer CJ, et al.: Presence of high-risk human papillomavirus DNA in penile carcinoma predicts favorable outcome in survival. Int J Cancer. 2006; 119: 1078-81.

16. Bezerra AL, Lopes A, Santiago GH, Ribeiro KC, Latorre MR, Villa LL: Human papillomavirus as a prognostic factor in carcinoma of the penis: analysis of 82 patients treated with amputation and bilateral lymphadenectomy. Cancer. 2001; 91: 2315-21.

Dr. David M. Prowse

Centre for Molecular Oncology, Institute of Cancer Bart's and The London Queen Mary's School of Medicine and Dentistry John Vane Science Centre London, United Kingdom E-mail:d.m.prowse@qmul.ac.uk 